\section{D) Check for updates}

Cite this: Dalton Trans., 2017, 46 13824

Received 20th June 2017 Accepted 19th July 2017

DOI: $10.1039 / \mathrm{c} 7 \mathrm{dt} 02238 \mathrm{~g}$ rsc.li/dalton

\title{
Desolvation and aggregation of sterically demanding alkali metal diarylphosphides $\uparrow$
}

\author{
Keith Izod, (D) * Peter Evans (D) and Paul G. Waddell
}

\begin{abstract}
The reaction between (Dipp) ${ }_{2} \mathrm{PH}$ and one equivalent of $n$ - $\mathrm{BuLi}, \mathrm{PhCH}_{2} \mathrm{Na}$ or $\mathrm{PhCH}_{2} \mathrm{~K}$ in $\mathrm{THF}$ gives the complexes [(Dipp) $\left.{ }_{2} \mathrm{P}\right] \mathrm{Li}(\mathrm{THF})_{3}(\mathbf{2 a}),\left\{\left[(\mathrm{Dipp})_{2} \mathrm{P}\right] \mathrm{Na}(\mathrm{THF})_{2}\right\}_{2}(3 \mathrm{a})$ and $\left[(\mathrm{Dipp})_{2} \mathrm{P}\right] \mathrm{K}(\mathrm{THF})_{4}(\mathbf{4 a})$, respectively [Dipp $\left.=2,6-\mathrm{iPr}_{2} \mathrm{C}_{6} \mathrm{H}_{3}\right]$. Exposure of these compounds to vacuum yields the alternative solvates $\left[(\mathrm{Dipp})_{2} \mathrm{P}\right] \mathrm{Li}(\mathrm{THF})_{2}(\mathbf{2 b}),\left[(\mathrm{Dipp})_{2} \mathrm{P}\right] \mathrm{Na}(\mathrm{THF})_{1.5}(\mathbf{3 b})$, and [(Dipp) $\left.{ }_{2} \mathrm{P}\right] \mathrm{K}(\mathbf{4} \mathbf{b})$, respectively; the alternative adduct [(Dipp) $\left.{ }_{2} \mathrm{P}\right] \mathrm{Na}(\mathrm{PMDETA})(3 \mathrm{c})$ was prepared by treatment of 3 a with PMDETA. Treatment of (Dipp)(Mes)PH or (Mes) $)_{2} \mathrm{PH}$ with one equivalent of $n$-BuLi in THF gives the complexes [(Dipp)(Mes)P]Li(THF) 3 (7a) and $\left[(\mathrm{Mes})_{2} \mathrm{P}_{2} \mathrm{Li}_{2}(\mathrm{THF})_{2}\left(\mathrm{OEt} \mathrm{t}_{2}\right)(\mathbf{8 a})\right.$ after crystallisation from diethyl ether [Mes = 2,4,6- $\left.\mathrm{Me}_{3} \mathrm{C}_{6} \mathrm{H}_{2}\right]$; crystallisation of $\mathbf{8} \mathbf{a}$ from hexane gives the alternative adduct $\left[(\mathrm{Mes})_{2} \mathrm{P}\right] \mathrm{Li}(\mathrm{THF})_{3}(\mathbf{8} \mathbf{b})$. Exposure of $\mathbf{7 a} \mathbf{a} \mathbf{8} \mathbf{a}$ and $\mathbf{8} \mathbf{b}$ to vacuum leads to loss of coordinated solvent, yielding the solvates [(Dipp)(Mes)P]Li(THF) $)_{2}$ (7b) and $\left[(\mathrm{Mes})_{2} \mathrm{P}\right] \mathrm{Li}(\mathrm{THF})(\mathbf{8 c})$. The solid-state structures of complexes $\mathbf{2} \mathbf{a}, \mathbf{3 a}, \mathbf{3 c}, \mathbf{4 a}, \mathbf{7} \mathbf{a}, \mathbf{8} \mathbf{a}$, and $\mathbf{8} \mathbf{b}$ have been determined by X-ray crystallography. Variable-temperature ${ }^{31} \mathrm{P}\left\{{ }^{1} \mathrm{H}\right\}$ and ${ }^{7} \mathrm{Li}$ NMR spectroscopy indicates that $\mathbf{2} \mathbf{b}, \mathbf{3} \mathbf{b}$ and $\mathbf{7 b}$ are subject to a monomer-dimer equilibrium in solution, where the monomeric forms are favoured at low temperature. In contrast, variable-temperature ${ }^{31} \mathrm{P}\left\{{ }^{1} \mathrm{H}\right\}$ and ${ }^{7} \mathrm{Li}$ NMR spectroscopy suggests that $\mathbf{8 c}$ is subject to a dynamic equilibrium between a dimer and a cyclic trimer in solution, where the trimer is favoured at low temperatures.
\end{abstract}

\section{Introduction}

Alkali metal phosphides are key intermediates in the synthesis of secondary and tertiary phosphine ligands and are ubiquitous metathesis reagents for the synthesis of main group, transition metal and f-element phosphide complexes. The alkali metal species are of interest in their own right and have been shown to adopt a wide variety of structural motifs in the solid state, ranging from monomers to dimers, trimers, tetramers, higher oligomers (often with ladder-like catenated $\mathrm{P}_{2} \mathrm{Li}_{2}$ rings), polymers, and 3-dimensional networks. ${ }^{1-11}$ The degree of oligomerisation is determined by the interplay between the size of the metal cation, the steric demands of the ligand substituents

Main Group Chemistry Laboratories, School of Chemistry, Bedson Building,

Newcastle University, Newcastle upon Tyne, NE1 $7 R U$, UK.

E-mail:keith.izod@ncl.ac.uk

$\dagger$ Electronic supplementary information (ESI) available: For 1, 2a, 3a, 3c, 4a, 7a, $\mathbf{8 a}$ and $\mathbf{8 b}$ details of structure determination, atomic coordinates, bond lengths and angles, and displacement parameters in CIF format. ${ }^{1} \mathrm{H},{ }^{13} \mathrm{C}\left\{{ }^{1} \mathrm{H}\right\},{ }^{7} \mathrm{Li}$ and ${ }^{31} \mathrm{P}\left\{{ }^{1} \mathrm{H}\right\}$ NMR spectra of $\mathbf{1}, \mathbf{2 b}, \mathbf{3 b}, \mathbf{3} \mathbf{c}, \mathbf{4} \mathbf{b}, \mathbf{7 b}$, and $\mathbf{8 b}$. CCDC 1557229-1557236. For ESI and crystallographic data in CIF or other electronic format see DOI: $10.1039 / \mathrm{c} 7 \mathrm{dt02238g}$. Data supporting this publication is openly available under an 'Open Data Commons Open Database License'. Additional metadata are available at DOI: 10.17634/154300-52. Please contact Newcastle Research Data Service at rdm@ncl.ac.uk for access instructions. and the presence of co-ligands such as THF, TMEDA and PMDETA [TMEDA $=N, N, N^{\prime}, N^{\prime}$-tetramethylethylenediamine, PMDETA $=N, N, N^{\prime}, N^{\prime \prime}, N^{\prime \prime}$-pentamethyldiethylenetriamine $] .{ }^{1}$

The oligomeric nature of alkali metal phosphides may be preserved in solution and, for lithium phosphides, ${ }^{31} \mathrm{P}$ and ${ }^{7} \mathrm{Li}$ NMR spectroscopy provide a convenient means for identifying oligomers and monitoring dynamic equilibria. ${ }^{3-5}$ In particular, coupling between these nuclei affords invaluable information on molecular connectivity; for monodentate phosphide ligands such coupling is often not observed at room temperature due to rapid exchange processes, but may be seen at low temperature, where these processes are frozen out. ${ }^{3}$ Solution-state studies of lithium phosphides have identified separated ion pairs, solvated monomers, and dimers containing a $\mathrm{P}_{2} \mathrm{Li}_{2}$ ring as the major species. $^{3}$ In addition, NMR studies suggest that [PhHP]Li adopts a cyclic trimeric structure in $\mathrm{Et}_{2} \mathrm{O}$ at $-73{ }^{\circ} \mathrm{C} .{ }^{4}$ Pulsed-gradient spin-echo ${ }^{7} \mathrm{Li}$ diffusion NMR experiments have also been used to show that $\left[\mathrm{Ph}_{2} \mathrm{P}\right] \mathrm{Li}$ adopts a monomeric structure in THF but a dimeric structure in diethyl ether. ${ }^{5}$

As part of a wider project investigating phosphorus-substituted heavier group 14 carbene analogues, ${ }^{12}$ we have recently prepared a series of alkali metal complexes with sterically demanding diarylphosphide ligands. Herein we present the crystal structures of these compounds, comment on the frequently observed coordinated solvent loss, and describe their solution behaviour. 


\section{Results and discussion}

The secondary phosphine (Dipp) 2 PH (1) has been reported previously by us, ${ }^{12 a}$ but its molecular structure has not been determined before [Dipp $\left.=2,6-\mathrm{iPr}_{2} \mathrm{C}_{6} \mathrm{H}_{3}\right]$. For the purposes of comparison, single crystals of $\mathbf{1}$ were obtained by sublimation at $100{ }^{\circ} \mathrm{C} / 10^{-3} \mathrm{mmHg}$ and its structure was determined by X-ray crystallography (Fig. 1). The crystal from which data were collected was twinned by pseudo-merohedry and the hydrogen atom bound to phosphorus and one isopropyl group were modelled as disordered over two positions.

Treatment of $\mathbf{1}$ with one equivalent of $n \mathrm{BuLi}$ in THF gives the corresponding lithium phosphide complex $\left[(\text { Dipp })_{2} \mathrm{P}\right] \mathrm{Li}(\mathrm{THF})_{3}$ (2a) as orange blocks after crystallisation from diethyl ether. A similar reaction between $\mathbf{1}$ and one equivalent of either $\mathrm{PhCH}_{2} \mathrm{Na}$ or $\mathrm{PhCH}_{2} \mathrm{~K}$ in THF gives the corresponding heavier alkali metal complexes $\left\{\left[(\mathrm{Dipp})_{2} \mathrm{P}\right] \mathrm{Na}(\mathrm{THF})_{2}\right\}_{2}$ (3a) and $\left[(\text { Dipp })_{2} \mathrm{P}\right] \mathrm{K}(\mathrm{THF})_{4}(\mathbf{4 a})$, respectively. The coordinated THF in 2a, 3a, and $\mathbf{4 a}$ is rapidly lost under vacuum, yielding the alternative solvates $\left[(\text { Dipp })_{2} \mathrm{P}\right] \mathrm{Li}(\mathrm{THF})_{2}(\mathbf{2 b}),\left[(\mathrm{Dipp})_{2} \mathrm{P}\right] \mathrm{Na}(\mathrm{THF})_{1.5}$ $(\mathbf{3 b})$, and the solvent-free complex $\left[(\mathrm{Dipp})_{2} \mathrm{P}\right] \mathrm{K}(\mathbf{4 b})$, respectively. Single crystals of $3 \mathbf{a}$ and $\mathbf{4 a}$ were obtained by crystallisation of the crude materials from a mixture of light petroleum and THF or diethyl ether and THF, respectively, while single crystals of the adduct [(Dipp) $\left.{ }_{2} \mathrm{P}\right] \mathrm{Na}$ (PMDETA) (3c) were obtained by crystallisation of 3 a from $n$-hexane in the presence of one equivalent of PMDETA.

The molecular structures of $\mathbf{2 a}, \mathbf{3 a}, \mathbf{3} \mathbf{c}$ and $\mathbf{4 a}$ are shown in Fig. 2, along with selected bond lengths and angles. Compound 2a crystallises with two crystallographically independent molecules in the unit cell, the conformations of which differ only marginally. The data for $\mathbf{4 a}$ are of rather poor quality and so any discussion of bond lengths and angles for this compound must be rather cautious. Overall the structures of $2 \mathbf{a}, 3 \mathbf{c}$ and $4 \mathbf{a}$ are rather similar, with the alkali metal ions

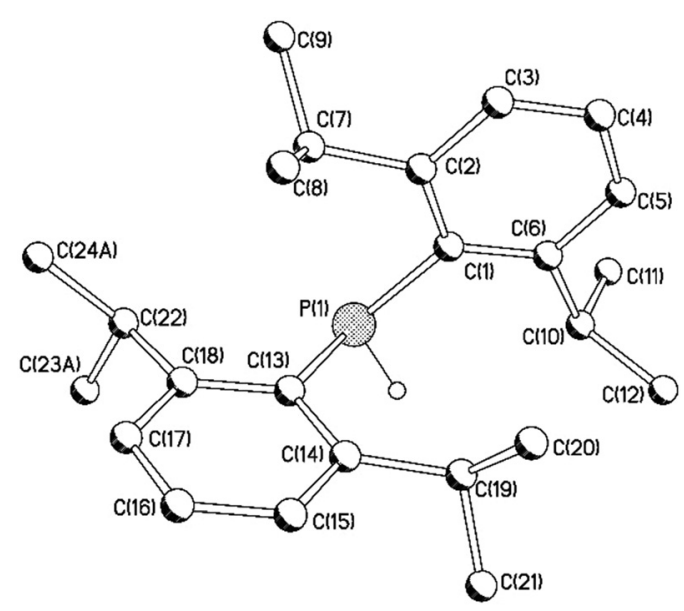

Fig. 1 Molecular structure of 1 with minor disorder components and $\mathrm{C}$-bound $\mathrm{H}$ atoms omitted for clarity. Selected bond lengths $(\AA \AA)$ and angles ( $\left.{ }^{\circ}\right)$ : $\mathrm{P}(1)-\mathrm{C}(1)$ 1.8536(14), $\mathrm{P}(1)-\mathrm{C}(13)$ 1.8527(15), $\mathrm{C}(1)-\mathrm{P}(1)-\mathrm{C}(13)$ 104.81(7). coordinated by the phosphide ligand and the $\mathrm{O}$ or $\mathrm{N}$ atoms of the co-ligands, resulting in distorted tetrahedral geometries at the metal centres in $\mathbf{2 a}$ and $\mathbf{3} \mathbf{c}$ and a distorted trigonal bipyramidal geometry at the potassium centre in $\mathbf{4 a}$. In addition, there is one short $\mathrm{Na} \cdots \mathrm{Me}(\mathrm{N})$ contact in $3 \mathrm{c}[\mathrm{Na}(1) \cdots \mathrm{C}(32) 3.121(17) \AA]$ and two short $\mathrm{K} \cdots \mathrm{CH}_{2}$ contacts in $4 \mathrm{a}[\mathrm{K}(1) \cdots \mathrm{C}(29) 3.505(13)$, $\mathrm{K}(1) \cdots \mathrm{C}(37)$ 3.537(13) $\AA$ ]. The P-M distances [2.482(3) (2a), 2.8745(12) (3c) and 3.221(2) $\AA$ (4a)] all lie at the shorter end of the range typical for such contacts. ${ }^{1}$ For example, the $\mathrm{Li}-\mathrm{P}$ distances in $\left[\left(\mathrm{Ph}_{2} \mathrm{P}\right) \mathrm{Li}(\mathrm{TMEDA})\right]_{2}$ range from $2.574(19)$ to $2.629(20) \AA{ }^{6}$ while the $\mathrm{Na}-\mathrm{P}$ distances in $[(\mathrm{CyPH}) \mathrm{Na}$ (PMDETA $)]_{2}$ are 2.884(8) and 2.936(7) $\AA^{7}{ }^{7}$ and the K-P distances in polymeric $\left[\left(\mathrm{Mes}^{*} \mathrm{PH}\right) \mathrm{K}\right]_{\infty}$ range from $3.181(2)$ to $3.357(2) \AA\left(\mathrm{Mes}^{*}=2,4,6-t \mathrm{Bu}_{3} \mathrm{C}_{6} \mathrm{H}_{2}\right) .{ }^{8}$ The phosphorus centres in 2a and 4a are close to planar [sum of angles at $\mathrm{P}=358.13(13)$ and $356.73(13)^{\circ}$ for the two independent molecules in 2a, and $359.97(20)^{\circ}$ for $4 \mathbf{a}$ ], whereas the phosphorus centre in $3 \mathbf{c}$ adopts a pyramidal geometry [sum of angles at $\mathrm{P}=$ $\left.322.73(17)^{\circ}\right]$.

In contrast, compound $\mathbf{3 a}$ crystallises as centrosymmetric dimers containing a planar $\mathrm{Na}_{2} \mathrm{P}_{2}$ rhombus-shaped core. Each sodium ion is further coordinated by two molecules of THF in a distorted tetrahedral geometry. The Na-P distances [2.9246(8) and $3.0178(8) \AA]$ are rather unsymmetrical, but are typical of Na- $\left(\mu-\mathrm{PR}_{2}\right)$ distances; for example, the Na-P distances in $\left[\mathrm{EtSi}\left\{\mathrm{PNa}\left(\mathrm{SiPr}_{3}^{\mathrm{i}}\right)\right\}_{3}\right]_{2} \cdot \mathrm{PhMe}$ range from $2.778(2)$ to $3.357(2) \AA{ }^{\circ}{ }^{9}$

Perhaps surprisingly, metalation of $\mathbf{1}$ has little impact on the gross structure of the (Dipp) ${ }_{2} \mathrm{P}$ framework: the P-C distances in $\mathbf{1}$ [1.8536(14) and 1.8257(15) $\mathrm{A}]$ are similar to the P-C distances in 2a, 3a, 3c and 4a [range 1.841(3)-1.8672(17) $\AA$ ] and the $\mathrm{C}(1)-\mathrm{P}(1)-\mathrm{C}(13)$ angle in $\mathbf{1}\left[104.81(17)^{\circ}\right]$ is similar to the corresponding angles in $\mathbf{2 a}, \mathbf{3 a}, \mathbf{3 c}$ and $\mathbf{4 a}$ [range 100.84(3)104.28(12) ${ }^{\circ}$.

Due to rapid solvent loss, it was not possible to obtain NMR spectra of 2a-4a; however, the ${ }^{1} \mathrm{H},{ }^{31} \mathrm{P}\left\{{ }^{1} \mathrm{H}\right\}$ and ${ }^{7} \mathrm{Li}$ NMR spectra of $\mathbf{2} \mathbf{b}$ and $\mathbf{3 b}$ suggest the operation of dynamic equilibria at room temperature (Fig. 3). At $90{ }^{\circ} \mathrm{C}$ the ${ }^{31} \mathrm{P}\left\{{ }^{1} \mathrm{H}\right\}$ NMR spectrum of $\mathbf{2 b}$ consists of a singlet at $-113.7 \mathrm{ppm}(\mathbf{A})$; as the temperature is reduced this signal broadens and begins to decoalesce, until, at room temperature, the spectrum consists of two very broad, overlapping signals at -106.0 (B) and $-118.3 \mathrm{ppm}(\mathrm{C})$. As the temperature is reduced further, these two signals sharpen and change in intensity: while at room temperature these two signals are in the approximate ratio of $1: 1.5$, as the temperature is reduced, the lower field signal (B) increases in intensity at the expense of the higher field signal (C), until, at $-80^{\circ} \mathrm{C}$, the two signals are in the ratio $1: 0.05$. At this latter temperature the two signals are clearly resolved as a $1: 1: 1: 1$ quartet $\left(J_{\mathrm{PLi}}=70.7 \mathrm{~Hz}\right)$ and a $1: 2: 3: 4: 3: 2: 1$ septet $\left(J_{\mathrm{PLi}}=67.1 \mathrm{~Hz}\right)$ at -104.0 and $-122.7 \mathrm{ppm}$, respectively. Similarly, at $90{ }^{\circ} \mathrm{C}$ the ${ }^{7} \mathrm{Li}$ NMR spectrum of $2 \mathbf{b}$ consists of a singlet at $2.1 \mathrm{ppm}(\mathrm{D})$. As the temperature is reduced, this signal broadens and decoalesces, until, at $0{ }^{\circ} \mathrm{C}$, the spectrum consists of two broad, overlapping signals at 2.5 (E) and $0.8 \mathrm{ppm}(\mathbf{F})$ of approximately equal intensity. These signals sharpen, resolve into a triplet and a doublet, respectively, and 


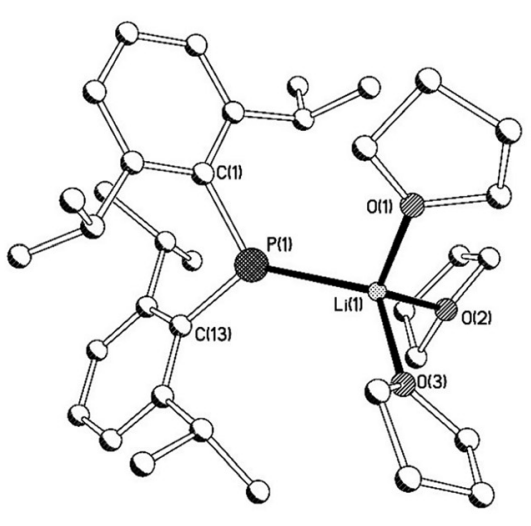

(a)

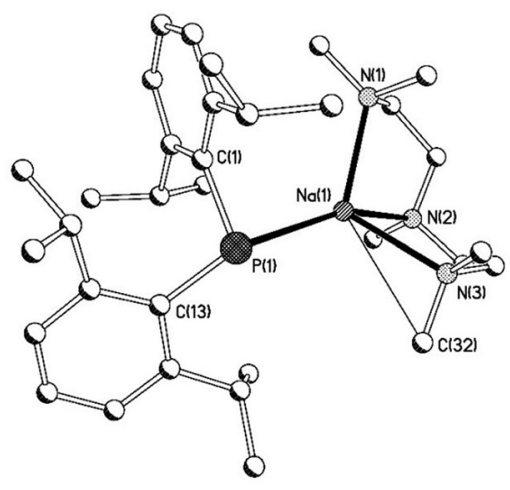

(c)

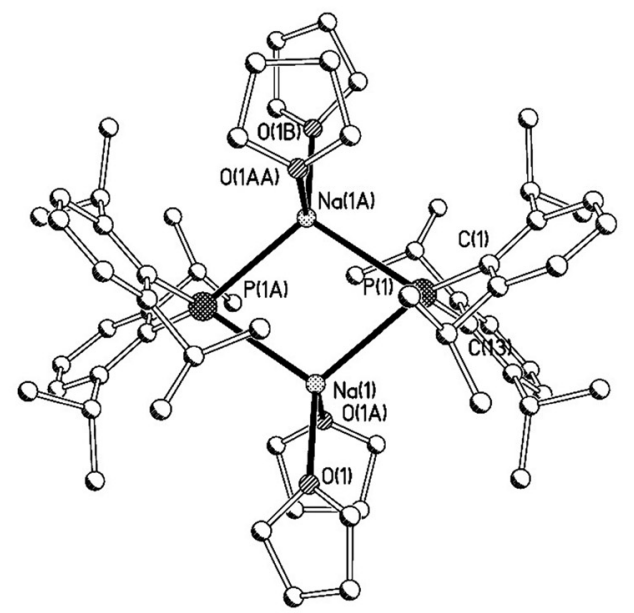

(b)

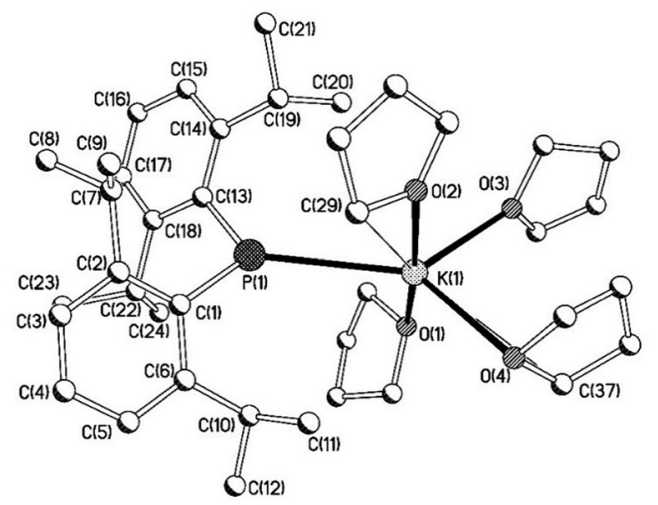

(d)

Fig. 2 Molecular structures of (a) 2a, (b) 3a, (c) 3c and (d) 4a with $\mathrm{H}$ atoms and disorder components omitted for clarity. Selected bond lengths (Å) and angles $\left({ }^{\circ}\right)$ : 2a (molecule 1) Li(1)-P(1) 2.482(3), Li(1)-O(1) 1.934(3), Li(1)-O(2) 1.948(3), Li(1)-O(3) 1.960(3), P(1)-C(1) 1.8474(15), P(1)-C(13) 1.8459(15), $\mathrm{Li}(1)-\mathrm{P}(1)-\mathrm{C}(1)$ 123.05(8), Li(1)-P(1)-C(13) 132.16(8), C(1)-P(1)-C(13) 102.92(6), (molecule 2) Li(2)-P(2) 2.498(3), Li(2)-O(4) 1.978(3), Li(2)-O(5) 1.934(3), $\mathrm{Li}(2)-\mathrm{O}(6 \mathrm{~A})$ 1.922(18), P(2)-C(37) 1.8506(15), P(2)-C(49) 1.8467(15), Li(2)-P(2)-C(37) 129.85(8), Li(2)-P(2)-C(49) 124.14(8), C(37)-P(2)-C(49) 102.74(6); 3a $\mathrm{Na}(1)-\mathrm{P}(1)$ 2.9246(8), $\mathrm{Na}(1)-\mathrm{P}(1 \mathrm{~A})$ 3.0178(8), $\mathrm{Na}(1)-\mathrm{O}(1)$ 2.3231(16), $\mathrm{Na}(1)-\mathrm{O}(1 \mathrm{~A})$ 2.343(4), $\mathrm{P}(1)-\mathrm{C}(1)$ 1.8672(17), $\mathrm{P}(1)-\mathrm{C}(13)$ 1.8622(16), $\mathrm{Na}(1)-\mathrm{P}(1)-$ $\mathrm{Na}(1 \mathrm{~A}) 73.83(2), \mathrm{P}(1)-\mathrm{Na}(1)-\mathrm{P}(1 \mathrm{~A})$ 106.17(2), $\mathrm{C}(1)-\mathrm{P}(1)-\mathrm{C}(13) 100.84(7) ; 3 \mathrm{c} \mathrm{Na}(1)-\mathrm{P}(1)$ 2.8745(12), $\mathrm{Na}(1)-\mathrm{N}(1) 2.509$ (9), $\mathrm{Na}$ (1)-N(2) 2.525(10), $\mathrm{Na}$ (1)-N(3) 2.472(10), $\mathrm{Na}(1) \ldots C(32) 3.121(17), P(1)-C(1)$ 1.856(3), $P(1)-C(13)$ 1.847(3), $\mathrm{Na}(1)-P(1)-C(1)$ 85.70(8), $\mathrm{Na}(1)-P(1)-C(13)$ 132.75(9), $C(1)-P(1)-C(13) 104.28(12)$; 4a $K(1)-P(1) 3.221(2), K(1)-O(1) 2.696(7), K(1)-O(2) 2.698(7), K(1)-O(3) 2.706(5), K(1)-O(4) 2.817(6), K(1) \ldots C(29) 3.505(13), K(1) \ldots C(37) 3.537(13), P(1)-C(1)$ 1.844(3), $P(1)-C(13) 1.841(3), K(1)-P(1)-C(1) 126.47(10), K(1)-P(1)-C(13) 130.00(10), C(1)-P(1)-C(13) 103.50(14)$.

rapidly change in intensity as the temperature is reduced further, such that, at $-80^{\circ} \mathrm{C}$, the spectrum consists of a triplet $\left(J_{\mathrm{PLi}}=71.4 \mathrm{~Hz}\right)$ and a doublet $\left(J_{\mathrm{PLi}}=68.9 \mathrm{~Hz}\right)$ at 2.8 and $0.4 \mathrm{ppm}$ in the approximate ratio of $0.08: 1$.

The variable-temperature ${ }^{31} \mathrm{P}\left\{{ }^{1} \mathrm{H}\right\}$ and ${ }^{7} \mathrm{Li}$ NMR spectra of 2b are consistent with a dynamic equilibrium between monomeric $2 \mathbf{b}$ and a dimeric species of the form $(\mathrm{THF})_{n} \mathrm{Li}\{\mu-\mathrm{P}$ $\left.(\text { Dipp })_{2}\right\}_{2} \mathrm{Li}(\mathrm{THF})_{n}$, which is rapid above room temperature. At lower temperatures the dimer appears to be disfavoured and the monomer predominates. The formation of a dimer is clearly associated with the loss of THF from 2 a under vacuum, which would leave each lithium three-coordinate in the monomer; however, the steric demands of the (Dipp) ${ }_{2} \mathrm{P}$ ligand appear to be sufficient that such a three-coordinate mono- meric species is stable. This behaviour is somewhat unusual, given that low temperatures typically favour the formation of higher aggregates.

Temperature-dependent NMR behaviour is not observed for 3c, but the variable-temperature ${ }^{31} \mathrm{P}\left\{{ }^{1} \mathrm{H}\right\}$ NMR spectra of $\mathbf{3 b}$ do exhibit behaviour consistent with the operation of one or more dynamic process(es) (Fig. 4). At $80^{\circ} \mathrm{C}$ the spectrum consists of a singlet at $-116.1 \mathrm{ppm}$ and this peak shifts to slightly higher field as the temperature is reduced. This may be attributed to a straightforward temperature dependence of the chemical shift caused by conformational changes within the compound and changes in intermolecular interactions with the solvent (a similar temperature dependence is observed for the free phosphine impurity 1). However, below $0{ }^{\circ} \mathrm{C}$, this peak begins to 


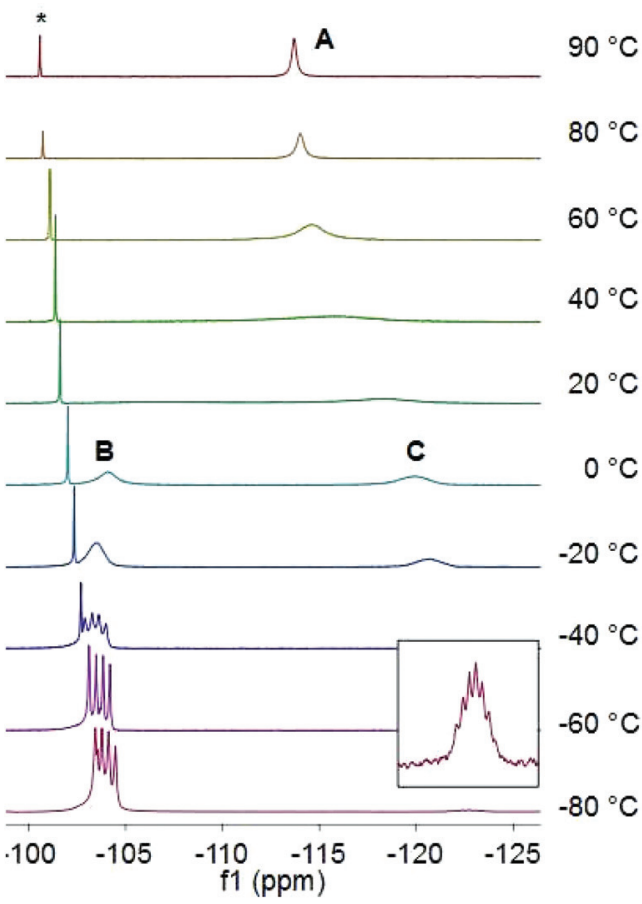

(a)

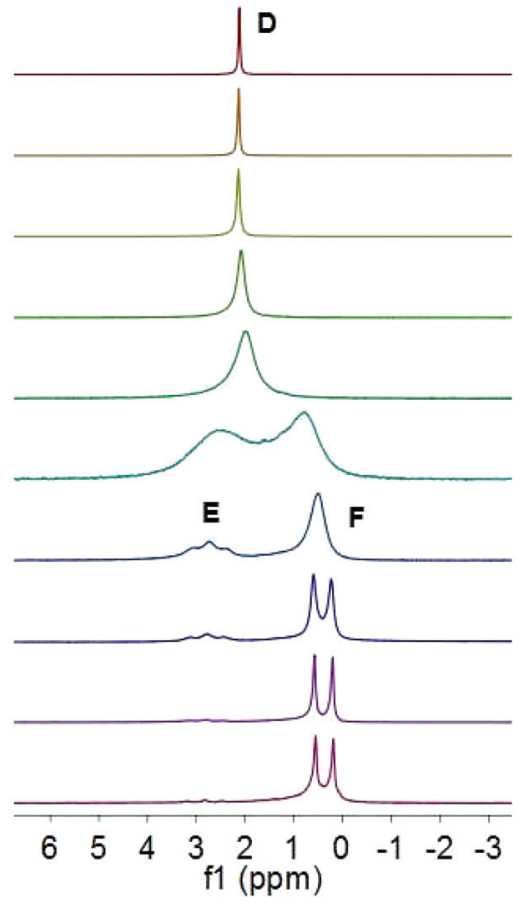

(b)

Fig. 3 Variable-temperature (a) ${ }^{31} \mathrm{P}\left\{{ }^{1} \mathrm{H}\right\}$ and (b) ${ }^{7} \mathrm{Li}$ NMR spectra of $2 \mathrm{~b}$ in $d_{8}$-toluene (* free phosphine 1).

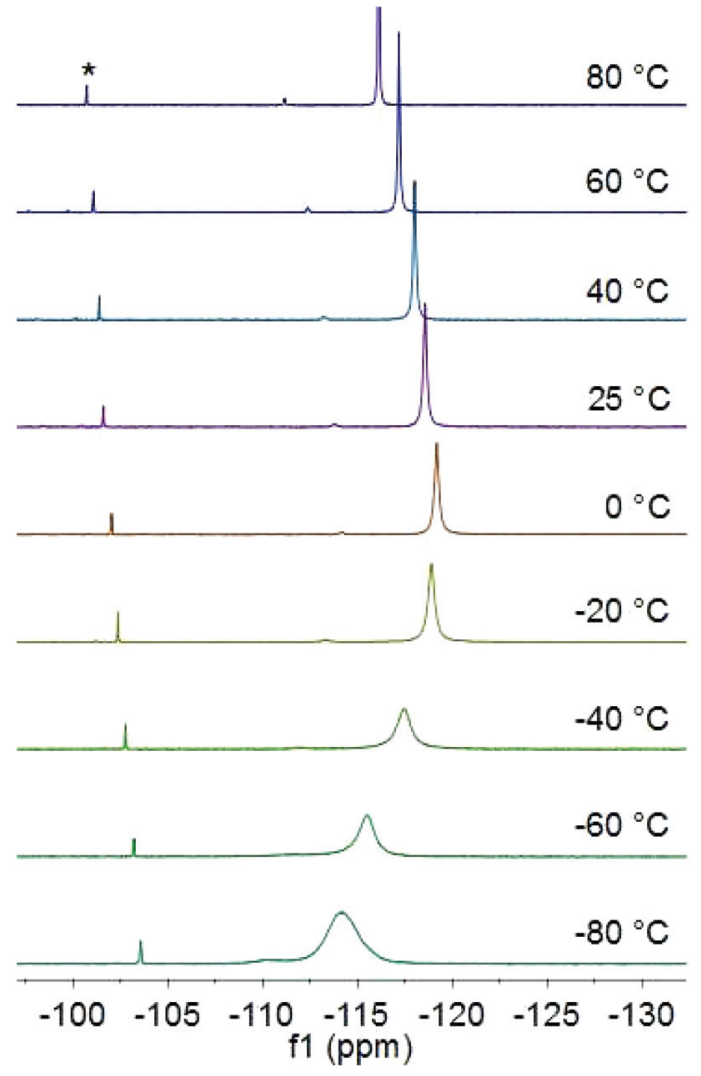

Fig. 4 Variable temperature ${ }^{31} \mathrm{P}\left\{{ }^{1} \mathrm{H}\right\}$ NMR spectra of $3 \mathrm{~b}$ in $d_{8}$-toluene (*free phosphine 1). broaden and to move to lower field, such that, at $-80^{\circ} \mathrm{C}$, the spectrum consists of a broad singlet at -114.1 ppm (FWHM $420 \mathrm{~Hz}$ ). These spectra are consistent with a dynamic equilibrium between a dimer similar to that observed in the solidstate structure of $\mathbf{3 a}$ and a monomeric (or possibly higher oligomeric) species.

Compound $\mathbf{4 b}$ has limited solubility in non-coordinating solvents and so a comparable variable-temperature NMR study is not possible; in THF solution compound $\mathbf{4 b}$ exhibits no evidence for dynamic behaviour.

Reducing the steric demands of the substituents at phosphorus might be expected to increase the tendency towards aggregation of the resulting lithium phosphides. In order to investigate this the lithiation of the new secondary phosphine (Dipp)(Mes)PH (5) and the known phosphine (Mes) ${ }_{2} \mathrm{PH}$ (6) was explored $\left[\mathrm{Mes}=2,4,6-\mathrm{Me}_{3} \mathrm{C}_{6} \mathrm{H}_{2}\right] \cdot{ }^{10}$ The secondary phosphine 5 was synthesised by the reaction between ( $\mathrm{Mes}) \mathrm{PCl}_{2}$ and one equivalent of $\mathrm{DippLi}\left(\mathrm{OEt}_{2}\right)$ in THF, followed by one equivalent of $\mathrm{LiAlH}_{4}$.

Treatment of 5 with one equivalent of $n \mathrm{BuLi}$ in THF gives the corresponding lithium phosphide [(Dipp)(Mes)P $] \mathrm{Li}(\mathrm{THF})_{3}$ (7a) after crystallisation from diethyl ether. It has been reported previously that the reaction between 6 and $n \mathrm{BuLi}$ in diethyl ether gives the dimer $\left[(\mathrm{Mes})_{2} \mathrm{P}\right]_{2} \mathrm{Li}_{2}\left(\mathrm{OEt}_{2}\right)_{2} \cdot{ }^{10}$ In contrast, the reaction between 6 and $n \mathrm{BuLi}$ in THF gives the alterative dinuclear complex $\left[(\mathrm{Mes})_{2} \mathrm{P}\right]_{2} \mathrm{Li}_{2}(\mathrm{THF})_{2}\left(\mathrm{OEt}_{2}\right)$ (8a) after crystallisation from diethyl ether; however, treatment of 6 with $n$ BuLi in THF, followed by crystallisation from $n$-hexane gives 
monomeric $\left[(\mathrm{Mes})_{2} \mathrm{P}\right] \operatorname{Li}(\mathrm{THF})_{3}(\mathbf{8 b})$. For 7a, 8a and $\mathbf{8 b}$, exposure to vacuum leads to loss of coordinated solvent, ultimately yielding the solvates $[(\mathrm{Dipp})(\mathrm{Mes}) \mathrm{P}] \mathrm{Li}(\mathrm{THF})_{2}(\mathbf{7 b})$ and $\left[(\mathrm{Mes})_{2} \mathrm{P}\right]$ Li(THF) (8c), which appear to be stable towards further solvent loss.

The molecular structures of $7 \mathbf{a}, \mathbf{8 a}$ and $\mathbf{8 b}$ are shown in Fig. 5, along with selected bond lengths and angles.

Compounds $\mathbf{7 a}$ and $\mathbf{8 b}$ crystallise as discrete monomers in which the lithium ions are coordinated by the phosphide $\mathrm{P}$ atom and the $\mathrm{O}$ atoms of three THF molecules in a distorted tetrahedral geometry. The Li-P distances in $7 \mathbf{a}$ and $\mathbf{8 b}$ [2.572(3) and $2.552(3) \AA$, respectively] are similar to previously reported Li-P distances; ${ }^{1,2}$ perhaps surprisingly, given the essentially isostructural nature of $\mathbf{2 b}, \mathbf{7} \mathbf{a}$ and $\mathbf{8 b}$, the Li-P distances do not correlate with the steric bulk of the phosphide ligands, decreasing in the order $7 \mathbf{a}>\mathbf{8 b}>\mathbf{2 a}$, i.e. with the shortest Li-P distance occurring in the complex with the most sterically demanding phosphide ligand. In both $7 \mathbf{a}$ and $\mathbf{8 b}$ the phosphorus atoms adopt a pyramidal geometry [sum of angles at $\mathrm{P}=331.41(17)(7 \mathbf{a})$ and $\left.330.58(17)^{\circ}(\mathbf{8 b})\right]$.

In contrast to $\mathbf{7 a}$ and $\mathbf{8 b}, \mathbf{8 a}$ crystallises as a phosphidebridged dimer with an essentially planar $\mathrm{P}_{2} \mathrm{Li}_{2}$ core. The two lithium ions in 8a are in distinct environments: $\mathrm{Li}(1)$ is coordinated by the two bridging phosphide ligands and two molecules of THF in a distorted tetrahedral geometry, while $\mathrm{Li}(2)$ is coordinated by the two phosphide ligands and a single molecule of diethyl ether in a trigonal planar geometry. The Li(1)-P distances [2.609(4) and 2.684(4) $\AA$ ] are significantly longer than the $\mathrm{Li}(2)-\mathrm{P}$ distances [2.513(4) and 2.518(4) $\AA$ ] and the $\mathrm{P}(1)-\mathrm{Li}(1)-\mathrm{P}(2)$ angle $\left[97.46(12)^{\circ}\right]$ is considerably smaller than the $\mathrm{P}(1)-\mathrm{Li}(2)-\mathrm{P}(2)$ angle $\left[104.53(13)^{\circ}\right]$, consistent with the lower coordination number at $\mathrm{Li}(2)$.

Once again, the variable temperature ${ }^{31} \mathrm{P}\left\{{ }^{1} \mathrm{H}\right\}$ and ${ }^{7} \mathrm{Li}$ NMR spectra of $\mathbf{7 b}$ indicate the operation of a dynamic process in

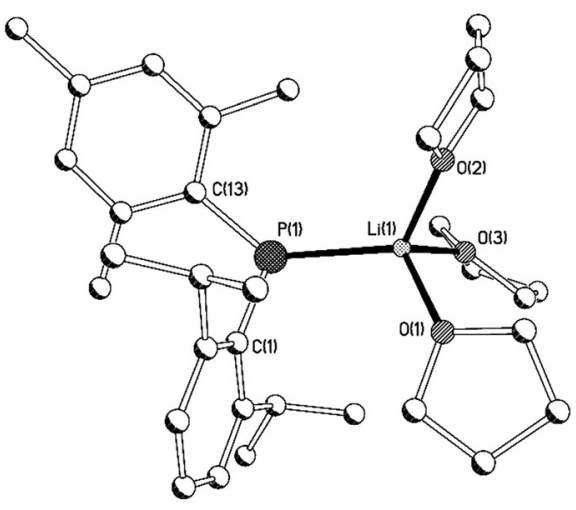

(a)

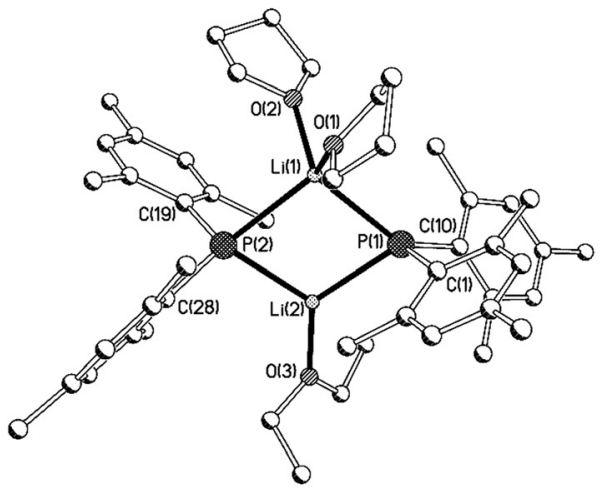

(b)

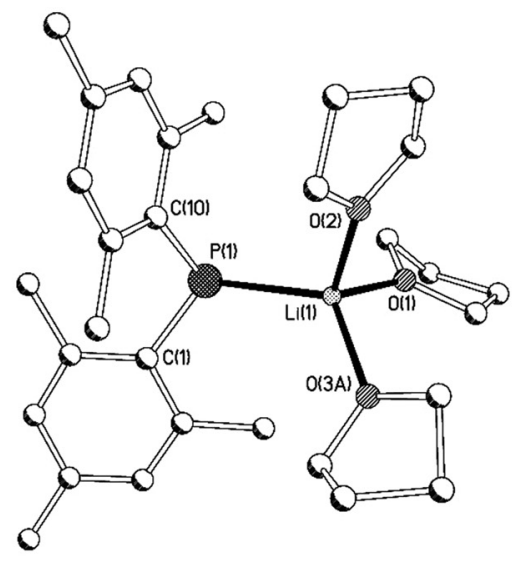

(c)

Fig. 5 Molecular structures of (a) 7a, (b) $8 \mathrm{a}$ and (c) $8 \mathrm{~b}$ with $\mathrm{H}$ atoms and disorder components omitted for clarity. Selected bond lengths ( $\AA$ ) and angles $\left({ }^{\circ}\right)$ : 7a Li(1)-P(1) 2.572(3), Li(1)-O(1) 1.963(4), Li(1)-O(2) 1.950(4), Li(1)-O(3) 1.999(4), P(1)-C(1) 1.854(2), P(1)-C(13) 1.832(2), Li(1)-P(1)-C(1) 99.42(10), Li(1)-P(1)-C(13) 127.65(10), C(1)-P(1)-C(13) 104.34(9); 8a Li(1)-P(1) 2.609(4), Li(1)-P(2) 2.684(4), Li(2)-P(1) 2.513(4), Li(2)-P(2) 2.518(4), $\mathrm{P}(1)-\mathrm{C}(1)$ 1.8365(18), $\mathrm{P}(1)-\mathrm{C}(10)$ 1.836(2), $\mathrm{P}(2)-\mathrm{C}(19)$ 1.8391(19), $\mathrm{P}(2)-\mathrm{C}(28)$ 1.840(2), $\mathrm{P}(1)-\mathrm{Li}(1)-\mathrm{P}(2)$ 97.46(12), P(1)-Li(2)-P(2) 104.53(13), Li(1)-P(1)$\mathrm{Li}(2)$ 79.69(12), Li(1)-P(2)-Li(2) 78.18(12); 8b Li(1)-P(1) 2.552(3), Li(1)-O(1) 1.944(3), Li(1)-O(2) 1.954(4), Li(1)-O(3B) 1.944(10), P(1)-C(1) 1.8164(19), $P(1)-C(10) 1.829(2), L i(1)-P(1)-C(1) 122.48(10), L i(1)-P(1)-C(10) 97.81(10), C(1)-P(1)-C(10) 110.29(9)$. 


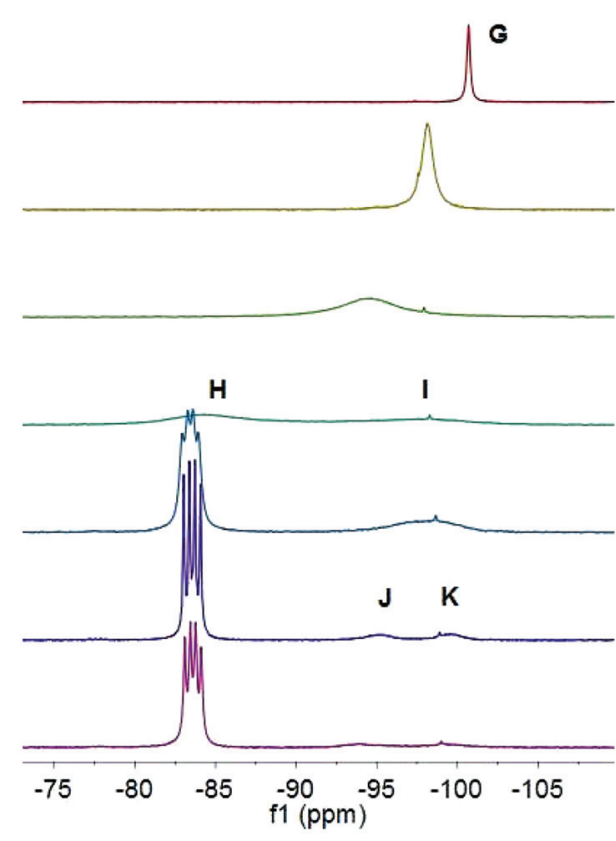

(a)

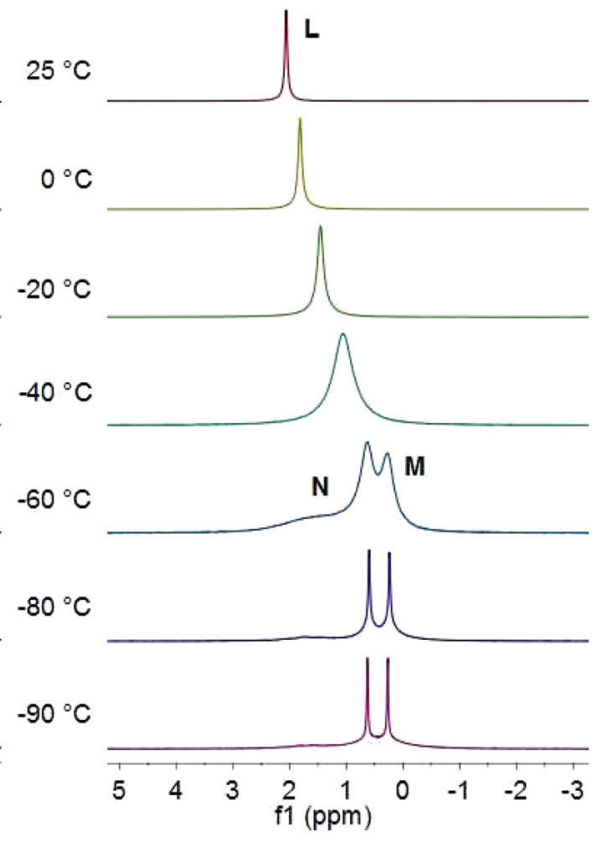

(b)

Fig. 6 Variable-temperature (a) ${ }^{31} \mathrm{P}\left\{{ }^{1} \mathrm{H}\right\}$ and (b) ${ }^{7} \mathrm{Li}$ NMR spectra of $7 \mathrm{~b}$ in $d_{8}$-toluene.

solution (Fig. 6). At room temperature the ${ }^{31} \mathrm{P}\left\{{ }^{1} \mathrm{H}\right\}$ NMR spectrum of $\mathbf{7 b}$ in $d_{8}$-toluene consists of a singlet at $-100.7 \mathrm{ppm}$ (G). As the temperature is reduced, this peak broadens and moves downfield, eventually decoalescing at $-40{ }^{\circ} \mathrm{C}$ into two broad signals at $-97.5(\mathbf{H})$ and $-84.4 \mathrm{ppm}(\mathbf{I})$. Below this temperature, peak $\mathbf{H}$ sharpens into a well-resolved quartet $\left(J_{\mathrm{PLi}}=69.5 \mathrm{~Hz}\right)$, while peak I further decoalesces into two low intensity, broad signals at approximately -99 (J) and $-94 \mathrm{ppm}(\mathbf{K})$ (approximate ratio of $\mathbf{H}: \mathbf{J}: \mathbf{K}$ at $-80{ }^{\circ} \mathrm{C} 12: 1: 1$ ). The room temperature ${ }^{7} \mathrm{Li}$ NMR spectrum of $\mathbf{7 b}$ consists of a single signal at $2.1 \mathrm{ppm}(\mathbf{L})$, which gradually decoalesces as the temperature is reduced until, at $-80{ }^{\circ} \mathrm{C}$, the spectrum consists of a sharp doublet at $0.4 \mathrm{ppm}\left(\mathbf{M}, J_{\mathrm{PLi}}=69.5 \mathrm{~Hz}\right)$ and a very broad, approximate triplet at $1.8 \mathrm{ppm}\left(\mathbf{N}, J_{\mathrm{PLi}}=48 \mathrm{~Hz}\right)$.

The variable-temperature ${ }^{31} \mathrm{P}\left\{{ }^{1} \mathrm{H}\right\}$ and ${ }^{7} \mathrm{Li}$ NMR spectra of $7 \mathbf{b}$ are consistent with a dynamic equilibrium between monomeric $(\mathbf{H} / \mathbf{M})$ and dimeric $(\mathbf{J}, \mathbf{K} / \mathbf{N})$ species in which the monomeric species is favoured at low temperatures. We assign the two higher field signals $\mathbf{J}$ and $\mathbf{K}$ in the low temperature ${ }^{31} \mathrm{P}$ $\left\{{ }^{1} \mathrm{H}\right\}$ NMR spectra to the cis and trans isomers of the dimer (Scheme 1), which appear to have equal probabilities. This behaviour is similar to that observed for 2; however, while, at room temperature, the time-averaged ${ }^{31} \mathrm{P}\left\{{ }^{1} \mathrm{H}\right\}$ NMR signal for

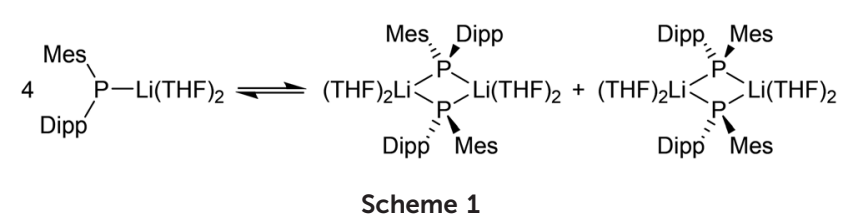

2b suggests equal proportions of monomer and dimer in equilibrium, the time-averaged room temperature ${ }^{31} \mathrm{P}\left\{{ }^{1} \mathrm{H}\right\}$ NMR signal for $\mathbf{7 b}$ lies to higher field than an arithmetical mean of the monomer and dimer signals would suggest, and so it appears that, for this compound, the dimeric form is substantially favoured at room temperature, even though this form is observed only in low concentrations at low temperatures.

Compound $\mathbf{8 c}$ exhibits rather different variable-temperature NMR spectra to both $2 \mathbf{b}$ and $7 \mathbf{b}$. At $80{ }^{\circ} \mathrm{C}$ the ${ }^{31} \mathrm{P}\left\{{ }^{1} \mathrm{H}\right\}$ NMR spectrum of $8 \mathbf{c}$ in $d_{8}$-toluene consists of a singlet $(\mathbf{O})$ at $-90.3 \mathrm{ppm}$ (Fig. 7). As the temperature is reduced, this peak broadens and moves to lower field, eventually decoalescing at $-40{ }^{\circ} \mathrm{C}$ into a broad signal $(\mathbf{P})$ at $-86.9 \mathrm{ppm}$, a well-resolved septet $(\mathbf{Q})$ at $-90.0 \mathrm{ppm}\left(J_{\mathrm{PLi}}=60.4 \mathrm{~Hz}\right)$, and a very broad, low intensity signal (R) at approximately $-95.5 \mathrm{ppm}$. As the temperature is decreased further, peak $\mathbf{Q}$ broadens and then sharpens again, while peak $\mathbf{P}$ moves to lower field and resolves into a complex multiplet, and peak $\mathbf{R}$ decreases in intensity, such that, at $-80^{\circ} \mathrm{C}$, the spectrum consists of a complex multiplet at -84.4 and a broad septet at $-91.0 \mathrm{ppm}$. The ${ }^{7} \mathrm{Li}$ NMR spectrum of $8 \mathrm{c}$ at $80^{\circ} \mathrm{C}$ consists of a singlet at $2.2 \mathrm{ppm}(\mathbf{S})$ and this moves slightly downfield and resolves at $-90{ }^{\circ} \mathrm{C}$ into a complex multiplet centred at approximately $2.7 \mathrm{ppm}$ that appears to consist of two overlying signals $(\mathbf{T} / \mathbf{U})$.

The low-field peak $\mathbf{P}$ observed in the $-80{ }^{\circ} \mathrm{C}^{31} \mathrm{P}\left\{{ }^{1} \mathrm{H}\right\}$ NMR spectrum of $\mathbf{8 c}$ is inconsistent with a dimeric structure. While the presence of a higher oligomer cannot be ruled out completely, simulation of this peak (Fig. 7d) is consistent with a cyclic trimer with ${ }^{1} J_{\mathrm{PLi}}=60 \mathrm{~Hz},{ }^{2} J_{\mathrm{PP}}=46 \mathrm{~Hz}$ and ${ }^{3} J_{\mathrm{PLi}}<5 \mathrm{~Hz}$; 


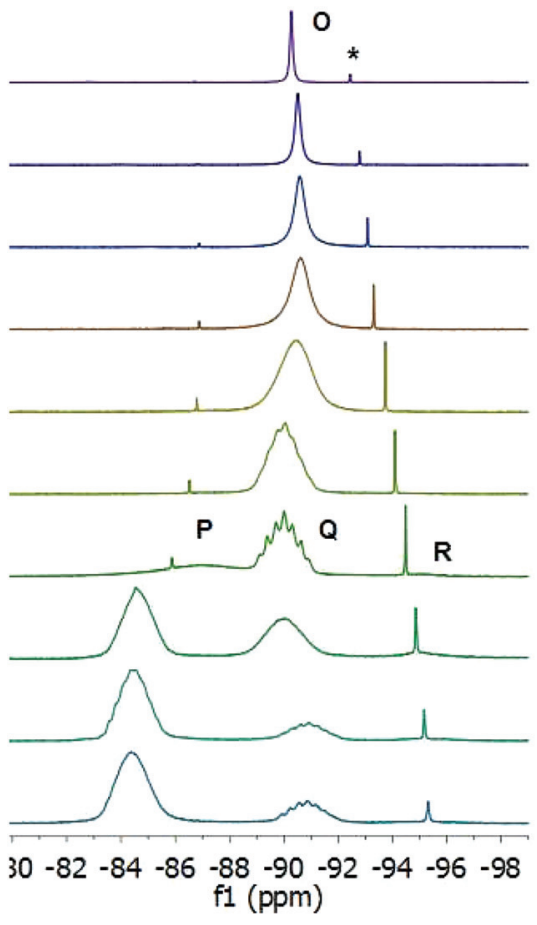

(a)

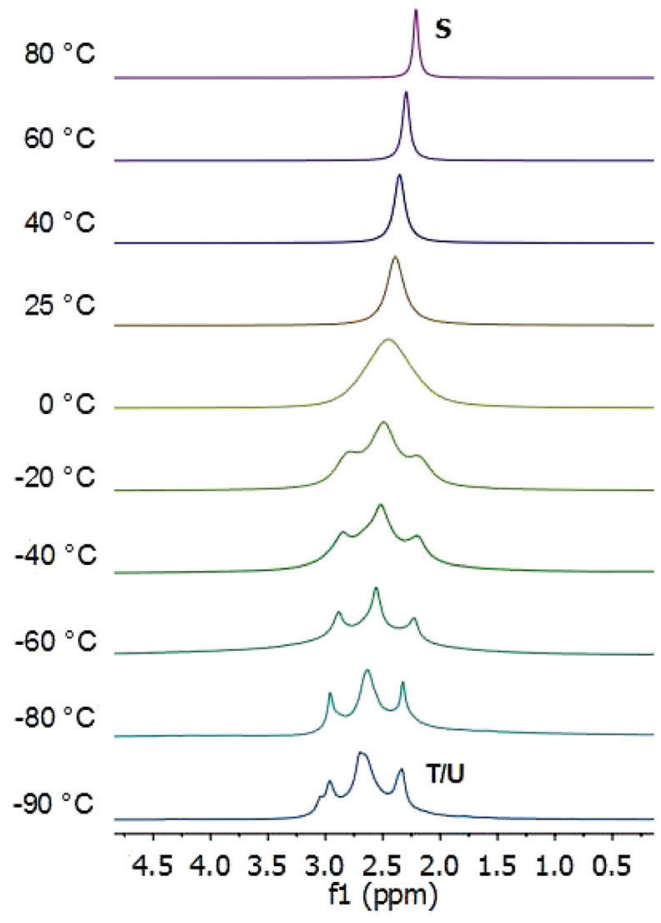

(b)

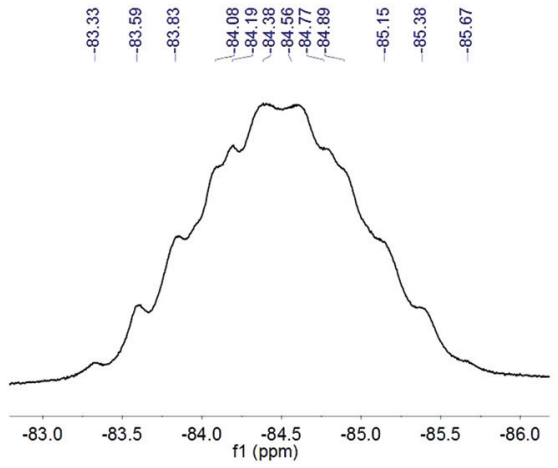

(c)

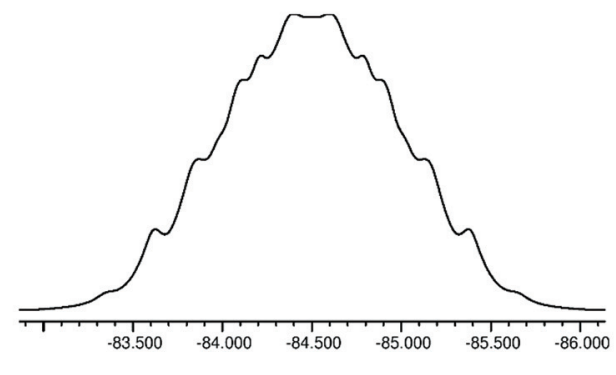

(d)

Fig. 7 Variable-temperature (a) ${ }^{31} \mathrm{P}\left\{{ }^{1} \mathrm{H}\right\}$ and (b) ${ }^{7} \mathrm{Li}$ NMR spectra of $8 \mathrm{c}$ in $d_{8}$-toluene ( ${ }^{\star}$ free phosphine 6); (c) expansion of the low-field ${ }^{31} \mathrm{P}\left\{{ }^{1} \mathrm{H}\right\}$ NMR signal $(P)$ at $-80^{\circ} \mathrm{C}$ and $(d)$ simulation of this peak.

simulations based on tetrameric oligomers did not give a successful match to the observed peak. The lineshape and calculated coupling constants for $\mathbf{8 c}$ are similar to those obtained for the proposed trimer $\left[(\mathrm{PhPH}) \mathrm{Li}\left(\mathrm{OEt}_{2}\right)_{n}\right]_{3}$ at $-73{ }^{\circ} \mathrm{C}$ in diethyl ether, the ${ }^{31} \mathrm{P}\left\{{ }^{1} \mathrm{H}\right\}$ NMR spectrum of which exhibits a complex multiplet with $J_{\mathrm{PLi}}=39 \mathrm{~Hz}, J_{\mathrm{PP}}=70 \mathrm{~Hz} .{ }^{4}$ The variable-temperature ${ }^{31} \mathrm{P}\left\{{ }^{1} \mathrm{H}\right\}$ and ${ }^{7} \mathrm{Li}$ NMR spectra of $\mathbf{8 c}$ are therefore consistent with a dynamic equilibrium between a dimer, a cyclic trimer (Scheme 2), and a further unidentified species which is in low concentration. For $\mathbf{2} \mathbf{b}$ and $\mathbf{7 b}$ the monomeric species gives rise to a quartet to significantly lower field than the peak due to the dimer, whereas peak $\mathbf{R}$ lies to higher field than peaks $\mathbf{Q}$ and $\mathbf{P}$ (assigned to the dimer and trimer, respectively),
3

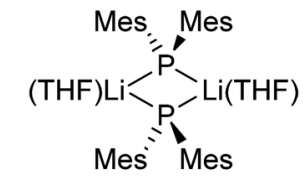

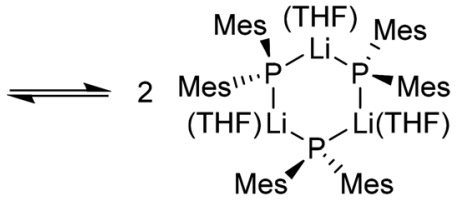

Scheme 2

suggesting that peak $\mathbf{R}$ is due to a higher oligomer, rather than a monomeric species.

A single example of a lithium phosphide with a crystallographically characterised cyclic trimeric structure has been 
reported: the sterically hindered tetrasilaphosphide $\left[\left[\left(\mathrm{iPr}_{2} \mathrm{Si}\right)_{4} \mathrm{P}\right] \mathrm{Li}\right]_{3}$ adopts a triangular structure in the solid state, but, unfortunately, the NMR data available for this compound are limited and the ${ }^{31} \mathrm{P}\left\{{ }^{1} \mathrm{H}\right\}$ NMR spectrum is reported as consisting of a broad singlet at room temperature, preventing comparisons with our data. ${ }^{12}$

\section{Conclusions}

The sterically-demanding alkali metal diarylphosphides 2, 3, 4, 7 and $\mathbf{8}$ are readily accessible and are potentially useful ligand transfer reagents. In the solid-state these compounds crystallise as either solvated monomers (2a, 3c, $4 \mathbf{a}, 7 \mathbf{a}, \mathbf{8 b})$ or phosphide-bridged dimers (3a, 8a); however, loss of coordinated solvent is common, leading to alternative solvates. Variable-temperature ${ }^{31} \mathrm{P}\left\{{ }^{1} \mathrm{H}\right\}$ and, where applicable, ${ }^{7} \mathrm{Li}$ NMR spectroscopy indicates that these less-solvated compounds are frequently subject to dynamic processes in solution and that the species present are dependent on the substituents at phosphorus. For $\mathbf{2 b}, \mathbf{3} \mathbf{b}$, and $\mathbf{7 b}$ this dynamic behaviour may be attributed to a monomer-dimer equilibrium, where the monomer is favoured at low temperatures, whereas for 8c there appears to be a dynamic equilibrium between a dimer and a cyclic trimer, where the trimer is favoured at low temperatures. The preference exhibited by $\mathbf{2 b}, \mathbf{3 b}$, and $\mathbf{7 b}$ for $\mathbf{a}$ monomeric structure in solution at low temperatures contrasts with the behaviour of less sterically hindered diarylphosphide complexes such as $\mathrm{Ph}_{2} \mathrm{PLi}(\mathrm{THF})_{n}{ }^{3}$ and 8c, which favour dimeric, or higher oligomeric, structures at low temperatures.

\section{Experimental}

All manipulations were carried out using standard Schlenk or dry-box techniques under an atmosphere of dry nitrogen or argon. THF, light petroleum (b.p. $40-60^{\circ} \mathrm{C}$ ), diethyl ether, and $n$-hexane were dried prior to use by distillation under nitrogen from sodium, potassium, or sodium/potassium alloy, as appropriate. THF and was stored over activated $4 \AA$ molecular sieves; all other solvents were stored over a potassium film. Deuterated THF and toluene were distilled from potassium and $\mathrm{CDCl}_{3}$ was distilled from $\mathrm{CaH}_{2}$ under nitrogen; all NMR solvents were deoxygenated by three freeze-pump-thaw cycles and were stored over activated $4 \AA$ molecular sieves. Benzylpotassium, ${ }^{13}$ benzylsodium, ${ }^{14}$ DippLi·OEt $_{2}{ }^{12 a}$ (Mes) $\mathrm{PCl}_{2}{ }^{15}$ and (Dipp) ${ }_{2} \mathrm{PH}^{12 a}$ were prepared by previously published procedures; the new adduct $\left[(\mathrm{Mes})_{2} \mathrm{P}\right]_{2} \mathrm{Li}_{2}\left(\mathrm{OEt}_{2}\right)(\mathrm{THF})_{2}$ (8a) was obtained by the reaction between (Mes) $)_{2} \mathrm{PH}$ and $n \mathrm{BuLi}$ in THF, followed by crystallization from cold $\left(-35^{\circ} \mathrm{C}\right)$ diethyl ether. $n$-Butyllithium was purchased from Aldrich as a $2.5 \mathrm{M}$ solution in hexanes. All other compounds were used as supplied by the manufacturer.

${ }^{1} \mathrm{H}$ NMR spectra were recorded on a Bruker Avance 300 or Avance400 spectrometer operating at 300.13 and $400.17 \mathrm{MHz}$, respectively; ${ }^{13} \mathrm{C}\left\{{ }^{1} \mathrm{H}\right\},{ }^{7} \mathrm{Li}$, and ${ }^{31} \mathrm{P}\left\{{ }^{1} \mathrm{H}\right\}$ NMR spectra were recorded on a Bruker Avance 500 spectrometer operating at 125.78, 194.38 and $202.44 \mathrm{MHz}$, respectively. ${ }^{1} \mathrm{H}$ and ${ }^{13} \mathrm{C}$ chemical shifts are quoted in ppm relative to tetramethylsilane, ${ }^{31} \mathrm{P}$ and ${ }^{7} \mathrm{Li}$ chemical shifts are quoted in ppm relative to external $85 \% \mathrm{H}_{3} \mathrm{PO}_{4}$ and $0.1 \mathrm{M} \mathrm{LiCl}$, respectively. Due to the air-sensitive nature of the alkali metal phosphides, we were unable to obtain consistent elemental analyses.

\section{Synthesis of $\left[(\operatorname{Dipp})_{2} \mathrm{P}\right] \operatorname{Li}(\mathrm{THF})_{2}(2 \mathrm{~b})$}

To a solution of (Dipp) $)_{2} \mathrm{PH}(0.695 \mathrm{~g}, 1.97 \mathrm{mmol})$ in $\mathrm{THF}$ $(10 \mathrm{ml})$ was added a solution of $n$ BuLi in hexanes $(2.3 \mathrm{M}$, $0.85 \mathrm{ml}, 2.0 \mathrm{mmol}$ ). The resulting red solution was stirred for $1 \mathrm{~h}$. The solvent was removed in vacuo and the orange solid was dissolved in $\mathrm{Et}_{2} \mathrm{O}(5 \mathrm{ml})$. Storage of this solution at $-25{ }^{\circ} \mathrm{C}$ for 2 days resulted in the formation of large yellow crystals of $\left[(\text { Dipp })_{2} \mathrm{P}\right] \mathrm{Li}(\mathrm{THF})_{3} \quad$ (2a). These crystals were washed with cold $\left(-10^{\circ} \mathrm{C}\right)$ light petroleum $(2 \times 5 \mathrm{ml})$ and residual solvent was removed in vacuo to give the alternative solvate $\left[(\mathrm{Dipp})_{2} \mathrm{P}\right] \mathrm{Li}(\mathrm{THF})_{2}(\mathbf{2 b})$ as a yellow powder. Yield of $2 \mathbf{b}: 0.79 \mathrm{~g}$, $80 \% .{ }^{1} \mathrm{H}$ NMR $\left[d_{8}\right.$-toluene, $\left.363 \mathrm{~K}\right]: \delta 0.99\left(\mathrm{~d}, J_{\mathrm{HH}}=6.9 \mathrm{~Hz}, 24 \mathrm{H}\right.$, $\mathrm{CHMe}_{2}$ ), 1.46 (m, 8H, THF), 3.57 (m, 8H, THF), 4.17 (m, 4H, $\mathrm{CHMe}$ ), 6.97 (d, $\left.J_{\mathrm{HH}}=7.7 \mathrm{~Hz}, 4 \mathrm{H}, \mathrm{ArH}\right), 7.04$ (m, 2H, ArH). ${ }^{7} \mathrm{Li} \quad \mathrm{NMR} \quad\left[d_{8}\right.$-toluene, $\left.363 \mathrm{~K}\right]: \begin{array}{llll}\delta & 2.2 & (\mathrm{~s}) .{ }^{13} \mathrm{C}\left\{{ }^{1} \mathrm{H}\right\} \quad \mathrm{NMR}\end{array}$ $\left[d_{8}\right.$-toluene, $\left.363 \mathrm{~K}\right]: \delta 25.00\left(\mathrm{CHMe}_{2}\right), 25.88$ (THF), 33.92 $\left(C \mathrm{HMe}_{2}\right), 68.61$ (THF), 123.29 (ArH), 125.47 (ArH), 147.00 (br. $\left.\mathrm{d}, J_{\mathrm{PC}}=23.1 \mathrm{~Hz}, \mathrm{Ar}\right), 152.85\left(\mathrm{~d}, J_{\mathrm{PC}}=6.2 \mathrm{~Hz}, \mathrm{Ar}\right) .{ }^{31} \mathrm{P}\left\{{ }^{1} \mathrm{H}\right\} \mathrm{NMR}$ [ $d_{8}$-toluene, $\left.363 \mathrm{~K}\right]: \delta-114.4$.

\section{Synthesis of $\left[(\text { Dipp })_{2} \mathrm{P}\right] \mathrm{Na}(\mathrm{THF})_{1.5}(3 \mathrm{~b})$}

To a solution of $\operatorname{Dipp}_{2} \mathrm{PH}(0.81 \mathrm{~g}, 2.28 \mathrm{mmol})$ in THF $(15 \mathrm{ml})$ was added a solution of benzylsodium $(0.261 \mathrm{~g}, 2.28 \mathrm{mmol})$ in THF $(10 \mathrm{ml})$. The resulting orange solution was stirred for $30 \mathrm{~min}$ and the solvent was removed in vacuo to give a sticky yellow solid. Light petroleum $(15 \mathrm{ml})$ was added to give an orange solution that spontaneously formed yellow crystals of $\left\{\left[(\text { Dipp })_{2} \mathrm{P}\right] \mathrm{Na}(\mathrm{THF})_{2}\right\}_{2}$ (3a). Further crystalline material was obtained by cooling the mixture to $-25{ }^{\circ} \mathrm{C}$ for $12 \mathrm{~h}$. The supernatant solution was removed by filtration and the crystals were washed with cold $\left(-10{ }^{\circ} \mathrm{C}\right)$ light petroleum. The residual solvent was removed under vacuum to give the alternative solvate $\left[(\mathrm{Dipp})_{2} \mathrm{P}\right] \mathrm{Na}(\mathrm{THF})_{1.5}(\mathbf{3 b})$ as a yellow powder. Yield of 3b: $0.89 \mathrm{~g}, 81 \%$. ${ }^{1} \mathrm{H}$ NMR [ $d_{8}$-toluene]: $\delta 1.04\left(\mathrm{~d}, J_{\mathrm{HH}}=6.9 \mathrm{~Hz}\right.$, 24H, CHMe $e_{2}$ ), 1.38 (m, 6H, THF), 3.50 (m, 6H, THF), 4.24 (m, $4 \mathrm{H}, \mathrm{CHMe}$ ), 7.03 (d, $\left.J_{\mathrm{HH}}=7.6 \mathrm{~Hz}, 4 \mathrm{H}, \mathrm{ArH}\right), 7.11(\mathrm{~m}, 2 \mathrm{H}$, $\mathrm{ArH}) .{ }^{13} \mathrm{C}\left\{{ }^{1} \mathrm{H}\right\}$ NMR $\left[d_{8}\right.$-toluene]: $\delta 24.54\left(\mathrm{CHMe}_{2}\right), 25.60$ (THF), $33.57\left(\mathrm{~d}, J_{\mathrm{PC}}=11.7 \mathrm{~Hz}, C \mathrm{HMe}_{2}\right), 68.19$ (THF), 122.95, 124.92 (ArH), 147.84 (d, $\left.J_{\mathrm{PC}}=33.5 \mathrm{~Hz}, \mathrm{Ar}\right), 151.98$ (d, $\left.J_{\mathrm{PC}}=4.8 \mathrm{~Hz}, \mathrm{Ar}\right)$. ${ }^{31} \mathrm{P}\left\{{ }^{1} \mathrm{H}\right\}$ NMR [ $d_{8}$-toluene]: $\delta-118.6$.

\section{Synthesis of $\left[(\text { Dipp })_{2} \mathrm{P}\right] \mathrm{Na}(\mathrm{PMDETA})(3 \mathrm{c})$}

(Dipp) ${ }_{2} \mathrm{PH}(0.596 \mathrm{~g}, 1.68 \mathrm{mmol})$ and benzylsodium $(0.194 \mathrm{~g}$, $1.70 \mathrm{mmol})$ were dissolved in THF $(10 \mathrm{ml})$ and this mixture was stirred for $1 \mathrm{~h}$ to give a red solution. The solvent was removed in vacuo. To the resulting orange solid was added $n$-hexane $(10 \mathrm{ml})$ and PMDETA $(0.35 \mathrm{ml}, 1.70 \mathrm{mmol})$ to give a red solution that deposited yellow crystalline material on 
standing. The mixture was cooled to $-25{ }^{\circ} \mathrm{C}$ for $2 \mathrm{~h}$, the supernatant was removed, the yellow crystalline material was washed with cold $\left(-10{ }^{\circ} \mathrm{C}\right)$ light petroleum $(2 \times 5 \mathrm{ml})$ and residual solvent was removed in vacuo. Yield: $0.60 \mathrm{~g}, 65 \%$. ${ }^{1} \mathrm{H}$ NMR [ $d_{8}$-toluene]: $\delta 1.21\left(\mathrm{~d}, J_{\mathrm{HH}}=7.0 \mathrm{~Hz}, 24 \mathrm{H}, \mathrm{CHMe} 2\right)$, 1.67 (br. s, $8 \mathrm{H}, \mathrm{NCH}_{2} \mathrm{CH}_{2} \mathrm{~N}$ ), 1.79 (s, $12 \mathrm{H}, \mathrm{NMe}_{2}$ ), 1.81 (s, 3H, NMe), 4.68 (m, 4H, CHMe $), 7.10$ (s, 6H, ArH). ${ }^{13} \mathrm{C}\left\{{ }^{1} \mathrm{H}\right\}$ NMR $\left[d_{8}\right.$-toluene]: $\delta 24.93\left(\mathrm{CHMe}_{2}\right), 33.18\left(\mathrm{CHMe}_{2}\right), 43.30(\mathrm{NMe})$, $45.28\left(\mathrm{NMe}_{2}\right), 54.03\left(\mathrm{NCH}_{2} \mathrm{CH}_{2} \mathrm{~N}\right), 56.97\left(\mathrm{NCH}_{2} \mathrm{CH}_{2} \mathrm{~N}\right), 122.42$, $123.20(\mathrm{ArH}), 151.88\left(\mathrm{~d}, J_{\mathrm{PC}}=7.3 \mathrm{~Hz}, \mathrm{Ar}\right), 152.92\left(\mathrm{~d}, J_{\mathrm{PC}}=\right.$ $49.3 \mathrm{~Hz}, \mathrm{Ar}) .{ }^{31} \mathrm{P}\left\{{ }^{1} \mathrm{H}\right\}$ NMR $\left[d_{8}\right.$-toluene]: $\delta-106.7$.

\section{Synthesis of $\left[(\mathrm{Dipp})_{2} \mathrm{P}\right] \mathrm{K}(\mathbf{4 b})$}

To a mixture of (Dipp) $)_{2} \mathrm{PH}(1.06 \mathrm{~g}, 2.99 \mathrm{mmol})$ and benzylpotassium $(0.391 \mathrm{~g}, 3.00 \mathrm{mmol})$ was added THF $(15 \mathrm{ml})$ and the resulting red solution was stirred for $1 \mathrm{~h}$. The solution was reduced in volume to $3 \mathrm{ml}$ in vacuo and light petroleum $(25 \mathrm{ml})$ was added, generating an orange precipitate. The solid was isolated by filtration, washed with light petroleum $(2 \times 5 \mathrm{ml})$ and dried in vacuo. Yield: $0.99 \mathrm{~g}, 84 \% .{ }^{1} \mathrm{H}$ NMR $\left[d_{8}\right.$-toluene $/ d_{8}$-THF]: $\delta 1.11\left(\mathrm{~d}, J_{\mathrm{HH}}=7.0 \mathrm{~Hz}, 24 \mathrm{H}, \mathrm{CHMe} e_{2}\right), 4.59$ $\left(\mathrm{m}, 4 \mathrm{H}, \mathrm{CHMe}_{2}\right), 6.92-6.96(\mathrm{~m}, 6 \mathrm{H}, \quad \mathrm{ArH}) .{ }^{13} \mathrm{C}\left\{{ }^{1} \mathrm{H}\right\} \quad \mathrm{NMR}$ $\left[d_{8}\right.$-toluene $/ d_{8}$-THF]: $\delta 24.81\left(\mathrm{CHMe}_{2}\right), 33.09\left(\mathrm{~d}, J_{\mathrm{PC}}=13.7 \mathrm{~Hz}\right.$, $\left.\mathrm{CHMe}_{2}\right), 122.27,122.50(\mathrm{ArH}), 151.93\left(\mathrm{~d}, J_{\mathrm{PC}}=8.2 \mathrm{~Hz}, \mathrm{Ar}\right)$, $154.68\left(\mathrm{~d}, J_{\mathrm{PC}}=55.8 \mathrm{~Hz}, \mathrm{Ar}\right) .{ }^{31} \mathrm{P}\left\{{ }^{1} \mathrm{H}\right\}$ NMR $\left[d_{8}\right.$-toluene $/ d_{8}$-THF $]$ : $\delta-92.3$.

Crystals of the solvate $\left[(\text { Dipp })_{2} \mathrm{P}\right] \mathrm{K}(\mathrm{THF})_{4}(\mathbf{4 a})$ suitable for characterisation by single crystal X-ray diffraction were obtained by recrystallization of $\mathbf{4 b}$ from an $\mathrm{Et}_{2} \mathrm{O} / \mathrm{THF}$ mixture at $-25{ }^{\circ} \mathrm{C}$. These crystals rapidly lose THF under vacuum to give the THF-free complex $\left[(\operatorname{Dipp})_{2} \mathrm{P}\right] \mathrm{K}(\mathbf{4 b})$.

\section{Synthesis of (Dipp)(Mes)PH (5)}

To a cold $\left(-78^{\circ} \mathrm{C}\right)$ solution of (Mes) $\mathrm{PCl}_{2}(2.99 \mathrm{~g}, 13.5 \mathrm{mmol})$ in $\mathrm{Et}_{2} \mathrm{O}(50 \mathrm{ml})$ was added a solution of DippLi.Et ${ }_{2} \mathrm{O}(3.28 \mathrm{~g}$, $13.5 \mathrm{mmol})$ in $\mathrm{Et}_{2} \mathrm{O}(20 \mathrm{ml})$. The resulting yellow solution was warmed to room temperature and stirred for $1 \mathrm{~h}$. The mixture was cooled to $-78{ }^{\circ} \mathrm{C}$ and solid $\mathrm{LiAlH}_{4}(0.511 \mathrm{~g}, 13.5 \mathrm{mmol})$ was added in portions. The mixture was warmed to room temperature and stirred for $1 \mathrm{~h}$. Degassed water $(40 \mathrm{ml})$ was added slowly, the product was extracted into light petroleum $(4 \times 20 \mathrm{ml})$ and the combined extracts were dried over $4 \AA$ molecular sieves. The solution was filtered and the solvent was removed under vacuum to yield $\mathbf{5}$ as a pale yellow solid. Yield: $3.29 \mathrm{~g}, 78 \% .{ }^{1} \mathrm{H}$ NMR $\left[\mathrm{CDCl}_{3}\right]: \delta 1.03\left(\mathrm{~d}, J_{\mathrm{HH}}=6.8 \mathrm{~Hz}, 6 \mathrm{H}\right.$, CHMeMe), 1.09 (d, $\left.J_{\mathrm{HH}}=6.8 \mathrm{~Hz}, 6 \mathrm{H}, \mathrm{CHMeMe}\right), 2.22(\mathrm{~s}, 6 \mathrm{H}$, $o-\mathrm{Me}), 2.23$ (s, 3H, $p-\mathrm{Me}), 3.59(\mathrm{~m}, 2 \mathrm{H}, \mathrm{CHMeMe}), 5.34$ (d, $J_{\mathrm{PH}}=$ $233 \mathrm{~Hz}, 1 \mathrm{H}, \mathrm{PH}), 6.80(\mathrm{~m}, 2 \mathrm{H}, \mathrm{ArH}), 7.11\left(\mathrm{~d}, J_{\mathrm{HH}}=7.7 \mathrm{~Hz}, 1 \mathrm{H}\right.$, $\operatorname{ArH}), 7.12\left(\mathrm{~d}, J_{\mathrm{HH}}=7.7 \mathrm{~Hz}, 1 \mathrm{H}, \mathrm{ArH}\right), 7.30\left(\mathrm{t}, J_{\mathrm{HH}}=7.7 \mathrm{~Hz}, 1 \mathrm{H}\right.$, ArH). ${ }^{13} \mathrm{C}\left\{{ }^{1} \mathrm{H}\right\}$ NMR [CDCl $]: \delta 21.05(o-\mathrm{Me}), 23.46\left(\mathrm{~d}, J_{\mathrm{PC}}=\right.$ $9.7 \mathrm{~Hz}, p$-Me), 23.86 (СНMеMe), 24.52 (СHMeMe), 32.84 $\left(\mathrm{d}, J_{\mathrm{PC}}=13.5 \mathrm{~Hz}, C \mathrm{HMeMe}\right), 123.40\left(\mathrm{~d}, J_{\mathrm{PC}}=3.4 \mathrm{~Hz}, \mathrm{ArH}\right)$, 129.25 (ArH), 129.28 (m, ArH), 130.47 (d, $\left.J_{\mathrm{PC}}=16.9 \mathrm{~Hz}, \mathrm{Ar}\right)$, $131.54\left(\mathrm{~d}, J_{\mathrm{PC}}=16.9 \mathrm{~Hz}, \mathrm{Ar}\right), 137.46(\mathrm{Ar}), 141.08\left(\mathrm{~d}, J_{\mathrm{PC}}=\right.$ $11.8 \mathrm{~Hz}, \mathrm{Ar}), 153.83\left(\mathrm{~d}, J_{\mathrm{PC}}=11.2 \mathrm{~Hz}, \mathrm{Ar}\right) .{ }^{31} \mathrm{P}\left[\mathrm{CDCl}_{3}\right]: \delta-96.9$ $\left(\mathrm{d}, J_{\mathrm{PH}}=233 \mathrm{~Hz}\right)$.

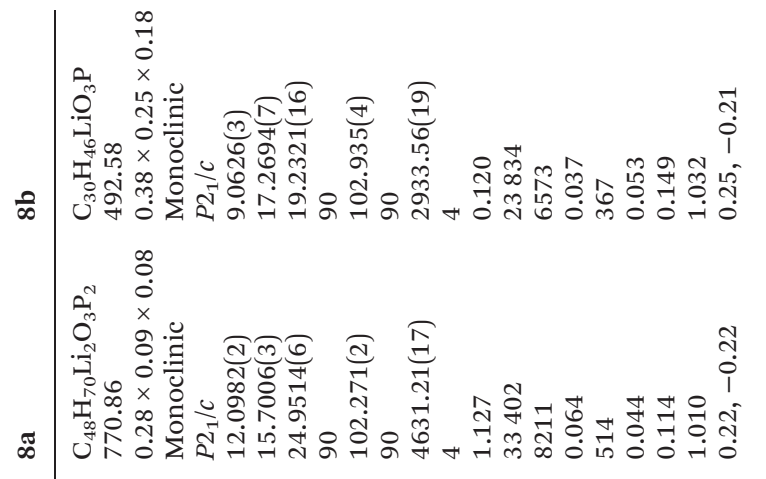

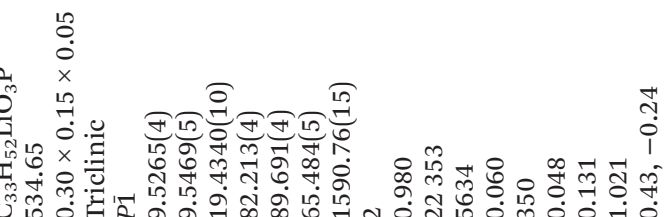

ก

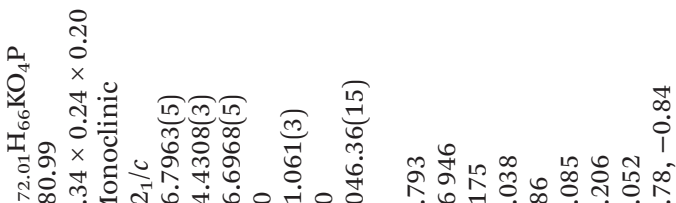

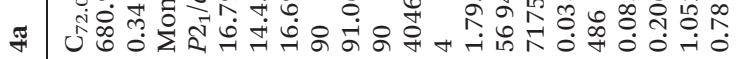

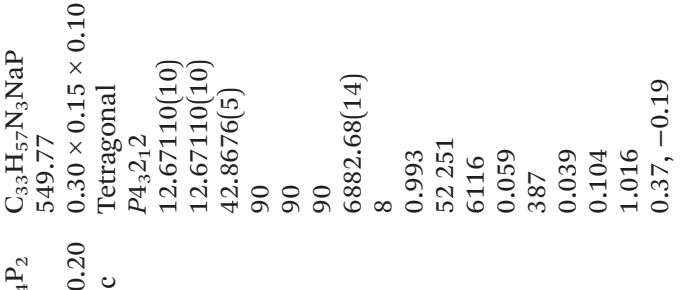

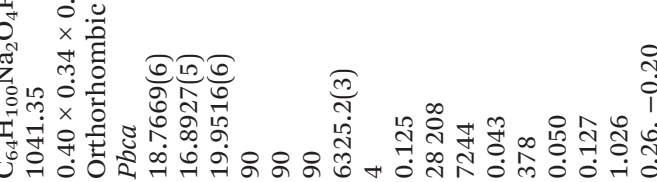

ल็

क

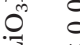

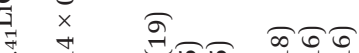

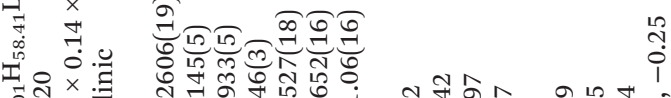

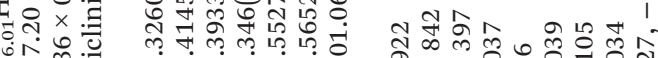

ส

웅

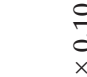
․․․ 


\section{Synthesis of $[(\mathrm{Dipp})(\mathrm{Mes}) \mathrm{P}] \mathrm{Li}(\mathrm{THF})_{2}(\mathbf{7 b})$}

To a solution of $5(0.55 \mathrm{~g}, 1.76 \mathrm{mmol})$ in THF $(10 \mathrm{ml})$ was added a solution of $n \mathrm{BuLi}$ in hexanes $(2.3 \mathrm{M}, 0.8 \mathrm{ml}$, $1.84 \mathrm{mmol}$ ). The resulting red solution was stirred for $1 \mathrm{~h}$ and the solvent was removed in vacuo. The resulting sticky orange solid was crystallized from cold $\left(-25^{\circ} \mathrm{C}\right) \mathrm{Et}_{2} \mathrm{O}(10 \mathrm{ml})$ to give large orange crystals of $[(\mathrm{Dipp})(\mathrm{Mes}) \mathrm{P}] \mathrm{Li}(\mathrm{THF})_{3}$ (7a). The crystals were isolated by filtration, washed with cold $\left(0{ }^{\circ} \mathrm{C}\right)$ light petroleum $(2 \times 5 \mathrm{ml})$ and residual solvent was removed under vacuum to give the alternative solvate $[(\mathrm{Dipp})(\mathrm{Mes}) \mathrm{P}] \mathrm{Li}(\mathrm{THF})_{2}$ (7b) as a yellow solid. Yield of $7 \mathbf{b}: 0.60 \mathrm{~g}, 74 \% .{ }^{1} \mathrm{H}$ NMR [ $d_{8}$-toluene, $\left.298 \mathrm{~K}\right]: 1.11\left(\mathrm{~d}, J_{\mathrm{HH}}=6.9 \mathrm{~Hz}, 12 \mathrm{H}, \mathrm{CHMe}_{2}\right), 1.37$ (m, 8H, THF), 2.20 (s, 3H, $p-\mathrm{Me}), 2.34$ (s, 6H, $o-\mathrm{Me}), 3.49$ (m, 8H, THF), 4.19 (m, 2H, CHMe $)_{2}, 6.81$ (s, 2H, ArH), 7.08 (d, $\left.J_{\mathrm{HH}}=7.6 \mathrm{~Hz}, 2 \mathrm{H}, \operatorname{ArH}\right), 7.14(\mathrm{~m}, 1 \mathrm{H}, \operatorname{ArH}) .{ }^{13} \mathrm{C}\left\{{ }^{1} \mathrm{H}\right\} \mathrm{NMR}$ $\left[d_{8}\right.$-toluene, $\left.298 \mathrm{~K}\right]: 20.67$ (p-Me), $24.36\left(\mathrm{CHMe}_{2}\right), 24.94$ (d, $\left.J_{\mathrm{PC}}=10.7 \mathrm{~Hz}, o-\mathrm{Me}\right), 25.23(\mathrm{THF}), 33.27$ (d, $J_{\mathrm{PC}}=12.3 \mathrm{~Hz}$, $\mathrm{CHMe}_{2}$ ), 67.84 (THF), 122.30, 124.79, 128.39 (ArH), 131.39 (Ar), $140.38\left(\mathrm{~d}, J_{\mathrm{PC}}=8.3 \mathrm{~Hz}, \mathrm{Ar}\right), 144.39\left(\mathrm{~d}, J_{\mathrm{PC}}=25.5 \mathrm{~Hz}, \mathrm{Ar}\right), 144.82$ $\left(\mathrm{d}, J_{\mathrm{PC}}=22.5, \mathrm{Ar}\right), 151.94\left(\mathrm{~d}, J_{\mathrm{PC}}=6.2 \mathrm{~Hz}, \mathrm{Ar}\right) \cdot{ }^{7} \mathrm{Li} \mathrm{NMR}$ [d $d_{8}$-toluene, $\left.298 \mathrm{~K}\right]: 2.1(\mathrm{~s}) .{ }^{31} \mathrm{P}\left\{{ }^{1} \mathrm{H}\right\}$ NMR $\left[d_{8}\right.$-toluene, $\left.298 \mathrm{~K}\right]$ : -100.7 (br. s).

Crystal structure determinations of $1,2 a, 3 a, 3 c, 4 a, 7 a, 8 a$ and $8 b$

Measurements were made at $150 \mathrm{~K}$ on an Oxford Diffraction (Agilent Technologies) Gemini A Ultra diffractometer using CuK $\alpha$ radiation $(\lambda=1.54178 \AA$; $1,2 \mathbf{2}, 3 \mathbf{c}, \mathbf{4 a}, 7 \mathbf{a}$ and $8 \mathbf{a})$ or MoK $\alpha$ radiation $(\lambda=0.71073 \AA$; $3 \mathbf{a}$ and $\mathbf{8 b})$. Cell parameters were refined from the observed positions of all strong reflections. Intensities were corrected for absorption using a multifaceted crystal model created by indexing the faces of the crystal for which data were collected for $\mathbf{1}, \mathbf{3 a}, \mathbf{4 a}, \mathbf{8 a}$ and $\mathbf{8 b},{ }^{16}$ and by empirical methods using spherical harmonics for $2 \mathbf{a}$, 3c and 7a. The structures were solved by direct methods and refined on $F^{2}$ values for all unique data; Table 1 gives further details. All non-hydrogen atoms were refined anisotropically, and $\mathrm{C}$-bound $\mathrm{H}$ atoms were constrained with a riding model; $U(\mathrm{H})$ was set at 1.2 (1.5 for methyl groups) times $U_{\text {eq }}$ for the parent $\mathrm{C}$ atom. The programs used were Rigaku Oxford Diffraction CrysAlisPro for data collection and processing, and Olex2 utilising SHELXT for structure solution and SHELXL for refinement, with molecular graphics produced using SHELXTL. ${ }^{17}$

\section{Acknowledgements}

The authors are grateful to Newcastle University and the UK Engineering and Physical Sciences Research Council (EPSRC, Grant No. EP/L5048281) for support. We thank Prof William McFarlane (Newcastle) for simulation of the ${ }^{31} \mathrm{P}\left\{{ }^{1} \mathrm{H}\right\}$ NMR spectrum of $\mathbf{8 c}$.

\section{References}

1 For a review see: K. Izod, Coord. Chem. Rev., 2000, 50, 33-108.
2 For selected examples see: (a) R. A. Jones, A. L. Stuart and T. C. Wright, J. Am. Chem. Soc., 1983, 105, 7459-7460; (b) G. W. Rabe, J. Riede and A. Schier, Acta Crystallogr., Sect. C: Cryst. Struct. Commun., 1996, 52, 1350-1352; (c) R. A. Bartlett, M. Olmstead and P. P. Power, Inorg. Chem., 1986, 25, 1243-1245; (d) P. B. Hitchcock, M. F. Lappert, P. P. Power and S. J. Smith, J. Chem. Soc., Chem. Commun., 1984, 1669-1670; (e) E. Hey-Hawkins and E. Sattler, J. Chem. Soc., Chem. Commun., 1992, 775-776; (f) M. Driess and H. Pritzkow, Z. Anorg. Allg. Chem., 1996, 622, 1524-1530; (g) G. W. Rabe, S. Kheradmandan and G. P. A. Yap, Inorg. Chem., 1998, 25, 6541-6543; (h) G. W. Rabe, S. Kheradmandan, L. M. Liable-Sands, I. A. Guzei and A. L. Rheingold, Angew. Chem., Int. Ed., 1998, 37, 1404-1407; (i) F. Dornhaus, M. Bolte, H.-W. Lerner and M. Wagner, Eur. J. Inorg. Chem., 2006, 1777-1785; (j) K. Izod, J. Stewart, E. R. Clark, W. Clegg and R. W. Harrington, Inorg. Chem., 2010, 49, 4698-4708; (k) R. Edge, R. J. Less, V. Nasari, E. J. L. McInnes and D. S. Wright, Dalton Trans., 2008, 64546460; (l) I. Jevtovikj, R. Herrero, S. Gomez-Ruiz, P. Lonnecke and E. Hey-Hawkins, Inorg. Chem., 2013, 52, 4488-4493; (m) C. von Hanisch, S. Traut and S. Stahl, Z. Anorg. Allg. Chem., 2007, 633, 2199-2204; (n) M. Westerhausen, T. Rotter, H. Görls, C. Birg, M. Warchold and H. Nöth, Z. Naturforsch., B: Chem. Sci., 2005, 60, 766-770.

3 (a) I. J. Colquhoun, H. C. E. McFarlane and W. McFarlane, J. Chem. Soc., Chem. Commun., 1982, 220-221; (b) R. A. Bartlett, M. M. Olmstead and P. P. Power, Inorg. Chem., 1986, 25, 1243-1247; (c) A. Zschunke, M. Riemer, H. Schmidt and K. Issleib, Phosphorus, Sulfur Relat. Elem., 1983, 17, 237-244; (d) H. J. Reich and R. R. Dykstra, Organometallics, 1994, 13, 4578-4585.

4 I. J. Colquhoun, H. C. E. McFarlane and W. McFarlane, Phosphorus Sulfur, 1983, 18, 61-64.

5 I. Fernandez, E. Martinez-Viviente and P. S. Pregosin, Inorg. Chem., 2004, 43, 4555-4557.

6 R. E. Mulvey, K. Wade, W. Clegg and D. Reed, Polyhedron, 1987, 6, 987-993.

7 E. Hey, C. L. Raston, B. W. Skelton and A. H. White, J. Organomet. Chem., 1989, 362, 1-10.

8 G. W. Rabe, G. P. A. Yap and A. L. Rheingold, Inorg. Chem., 1997, 36, 1990-1991.

9 M. Driess, G. Huttner, N. Knopf, H. Pritzow and L. Asolnai, Angew. Chem., Int. Ed. Engl., 1995, 34, 316-318.

10 R. A. Bartlett, M. M. Olmstead, P. P. Power and G. A. Sigel, Inorg. Chem., 1987, 26, 1941-1946.

11 S. Traut, C. von Hänisch and H.-J. Kathagen, Eur. J. Inorg. Chem., 2009, 777-783.

12 (a) K. Izod, D. G. Rayner, S. M. El-Hamruni, R. W. Harrington and U. Baisch, Angew. Chem., Int. Ed., 2014, 53, 3636-3640; (b) K. Izod, P. Evans, P. G. Waddell and M. R. Probert, Inorg. Chem., 2016, 55, 10510-10522; (c) K. Izod, P. Evans and P. G. Waddell, Angew. Chem., Int. Ed., 2017, 56, 5593-5597.

13 L. Lochmann and J. Trekoval, J. Organomet. Chem., 1987, 326, 1-7. 
14 S. Corbelin, N. P. Lorenzen, J. Kopf and E. Weiss, J. Organomet. Chem., 1991, 415, 293-313.

15 D. Bockfield, A. Doddi, P. G. Jones and M. Tamm, Eur. J. Inorg. Chem., 2016, 3704-3713.

16 R. C. Clark and J. S. Reid, Acta Crystallogr., Sect. A: Fundam. Crystallogr., 1995, 51, 887.
17 (a) CrysAlisPro, Agilent Technologies, Version 1.171.36; (b) G. M. Sheldrick, Acta Crystallogr., Sect. A: Fundam. Crystallogr., 2015, 71, 3-8; (c) G. M. Sheldrick, Acta Crystallogr., Sect. A: Fundam. Crystallogr., 2008, 64, 112-122; (d) O. V. Dolomanov, L. J. Bourhis, R. J. Gildea, J. A. K. Howard and H. Puschmann, J. Appl. Crystallogr., 2009, 42, 339-341. 